\title{
Analisis Faktor Yang Memengaruhi Minat Berkunjung Masyarakat Ke Pos Pembinaan Terpadu Penyakit Tidak Menular Di UPTD Puskesmas Lahusa Kecamatan Lahusa Kabupaten Nias Selatan
}

\author{
Samsidar Duha*, Tri Niswati Utami, Achmad Rifai \\ S2 IImu Kesehatan Masyarakat, Institut Kesehatan Helvetia Medan \\ *Email : samsidarduha85@gmail.com
}

\begin{abstract}
ABSTRAK
Penyakit Tidak Menular (PTM) merupakan masalah bagi kesehatan masyarakat, sehingga diperlukan upaya pencegahan faktor risiko. Penelitian ini bertujuan untuk menganalisis faktor yang memengaruhi minat berkunjung masyarakat ke pos pembinaan terpadu penyakit tidak menular di UPTD Puskesmas Lahusa Kecamatan Lahusa Kabupaten Nias Selatan. Penelitian ini menggunakan rancangan cross sectional study. Penelitian berlangsung mulai bulan Juni sampai dengan Juli 2020 dengan jumlah sampel sebanyak 95 orang yang diperoleh dengan menggunakan purposive sampling,. Data hasil survey dianalisis dengan menggunakan uji Chi Square dan regresi logistik. Hasil penelitian menunjukkan bahwa ada pengaruh pengetahuan terhadap minat berkunjung ke Posbindu PTM, ada pengaruh pendidikan terhadap minat berkunjung ke Posbindu PTM, ada pengaruh jarak terhadap minat berkunjung ke Posbindu PTM, ada pengaruh pekerjaan terhadap minat berkunjung ke Posbindu PTM, ada pengaruh penghasilan terhadap minat berkunjung ke Posbindu PTM, ada pengaruh dukungan keluarga terhadap minat berkunjung ke Posbindu PTM, ada pengaruh dukungan tenaga kesehatan terhadap minat berkunjung ke Posbindu PTM di UPTD Puskesmas Lahusa Kecamatan Lahusa Kabupaten Nias Selatan. Adapun variabel yang paling berpengaruh dominan terhadap minat berkunjung ke Posbindu PTM di UPTD Puskesmas Lahusa Kecamatan Lahusa Kabupaten Nias Selatan adalah dukungan keluarga. Saran dalam penelitian ini yaitu agar masyarakat meningkatkan pengetahuan dengan aktif mengikuti Posbindu PTM untuk mencegah terjadinya penyakit tidak menular. Selain meningkatkan pengetahuan diharapkan keluarga meningkatkan dukungannya terhadap anggota keluarga yang mengikuti Posbindu PTM dengan bersedia mengantarkan ke Posbindu PTM dan mendampinginya.
\end{abstract}

\section{Kata Kunci :Pengetahuan, Pendidikan, Penghasilan, Dukungan Keluarga, Dukungan Tenaga Kesehatan}

\begin{abstract}
Non-Communicable Diseases (PTM) is a problem for public health, so efforts to prevent risk factors are needed. This study aims to analyze the factors that influence the interest in visiting the community to an integrated non-communicable disease guidance post at the UPTD Puskesmas Lahusa, Lahusa District, South Nias Regency. This study used a cross sectional study design. The research took place from June to July 2020 with a total sample of 95 people who were obtained using purposive sampling. Survey data were analyzed using the Chi Square test and logistic regression. The results showed that there was an influence of knowledge on the interest in visiting Posbindu PTM, there was an effect of education on the interest in visiting Posbindu PTM, there was an effect of distance on the interest in visiting Posbindu PTM, there was an effect of work on the interest in visiting Posbindu PTM, there was an effect of income on the interest in visiting to Posbindu PTM, there is an effect of family support on interest in visiting Posbindu PTM, there is an effect of support from health workers on interest in visiting Posbindu PTM at UPTD Puskesmas Lahusa, Lahusa District, South Nias Regency. The variable that most influences the interest in visiting Posbindu PTM at the UPTD Lahusa Puskesmas, Lahusa District, South Nias Regency is family support. Suggestions in this study are for the public to increase their knowledge by actively participating in Posbindu PTM to prevent noncommunicable diseases. In addition to increasing knowledge, it is hoped that the family will increase their support for family members who take part in the PTM Posbindu by being willing to take them to Posbindu PTM and accompany them.
\end{abstract}

Keywords: Knowledge, Education, Income, Family Support, Health Worker Support. 


\section{PENDAHULUAN}

Penyakit tidak menular (PTM) telah menjadi masalah besar di masyarakat Indonesia. Penyakit Tidak Menular (PTM) cenderung terus meningkat secara global dan nasional telah menduduki sepuluh besar penyakit penyebab kematian.

Berdasarkan data World Health Organization 2018 WHO sekitar $71 \%$ penyebab kematian di dunia adalah penyakit tidak menular (PTM) yang membunuh 36 juta jiwa per tahun. Sekitar 80 persen kematian tersebut terjadi di negara berpenghasilan menengah dan rendah. $73 \%$ kematian saat ini disebabkan oleh penyakit tidak menular, 35\% diantaranya karena penyakit jantung dan pembuluh darah, $12 \%$ oleh penyakit kanker, $6 \%$ oleh penyakit pernapasan kronis, 6\% karena diabetes, dan $15 \%$ disebabkan oleh Penyakit Tidak Menular (PTM)lainnya. ${ }^{1}$

Data Kementerian Kesehatan Republik Indonesia (Kemenkes RI) tahun 2018 diketahui bahwa Penyakit Tidak Menular (PTM) menjadi penyebab kematian di Indonesia mengalami peningkatan cukup tinggi, dari $41,7 \%$ tahun 1995, menjadi $49,9 \%$ tahun 2001 , dan $59,5 \%$ tahun 2007. ${ }^{2}$ Pada tahun 2011 terjadi peningkatan 64\%, dan tahun 2016 kematian sebanyak 1.551 .000 jiwa, diperkirakan mencapai $71 \%$ disebabkan oleh Penyakit Tidak Menular (PTM), terdiri atas penyakit kardiovaskuler/jantung 37\%, kanker $13 \%$, penyakit paru kronis $5 \%$, diabetes $6 \%$, dan penyakit tidak menular lainnya $10 \%{ }^{3}$

Keprihatinan terhadap peningkatan prevalensi Penyakit Tidak Menular (PTM) telah mendorong lahirnya kesepakatan tentang strategi global dalam pencegahan dan pengendalian Penyakit Tidak Menular (PTM), khususnya di negara berkembang. Penyakit Tidak Menular (PTM) telah menjadi isu strategis dalam agenda SDGs 2030 sehingga harus menjadi prioritas pembangunan di setiap negara. Indonesia saat ini menghadapi beban ganda penyakit, yaitu penyakit menular dan Penyakit Tidak Menular. Perubahan pola penyakit tersebut sangat dipengaruhi antara lain oleh perubahan lingkungan, perilaku masyarakat, transisi, demografi teknologi, ekonomi dan sosial budaya.

Riskesdas tahun 2018 menunjukkan bahwa terjadi peningkatan pada indikator-indikator kunci Penyakit Tidak Menular (PTM) yang tercantum dalam Rencana Pembangunan Jangka Panjang Nasional tahun 2015-2019, sebagai berikut : Prevalensi tekanan darah tinggi pada penduduk usia 18 tahun keatas meningkat dari $25,8 \%$ menjadi $34,1 \%$; Prevalensi obesitas penduduk usia 18 tahun ke atas meningkat dari $14,8 \%$ menjadi $21,8 \%$; Prevalensi merokok penduduk usia $\leq 18$ tahun meningkat dari $7,2 \%$. menjadi $9,1 \%{ }^{4}$

Berdasarkan data Profil Dinas Kesehatan Sumatera Utara tahun 2018 prevalensi Penyakit Tidak Menular (PTM) di Sumatera Utara lebih tinggi dibanding prevalensi nasional. Di antaranya, hipertensi mencapai 28,1 persen dibandingkan nasional hanya 24,7 persen. Prevalensi diabetes mellitus mencapai 2,9 persen, dibanding nasional hanya 2,3 persen. Begitu juga dengan prevalensi kanker dan gagal jantung.

Meningkatnya kasus Penyakit Tidak Menular (PTM) secara significan diperkirakan akan menambah beban masyarakat dan pemerintah, karena penanganannya membutuhkan biaya yang besar dan memerlukan teknologi tinggi. Hal ini dapat terlihat dari data Badan Penyelenggara Jaminan Sosial Kesehatan (BPJS) tahun 2017, sebanyak 10.801.787 juta orang atau 5,7\% peserta JKN mendapat pelayanan untuk penyakit katastropik dan menghabiskan biaya kesehatan sebesar 14,6 triliun rupiah atau $21,8 \%$ dari seluruh biaya pelayanan kesehatan dengan komposisi peringkat penyakit jantung sebesar $50,9 \%$ atau 7,4 triliun, penyakit ginjal kronik sebesar $17,7 \%$ atau 2,6 triliun rupiah. Kondisi peningkatan penderita Penyakit Tidak Menular (PTM) dan penyebab kematian di Indonesia, merupakan masalah bagi kesehatan masyarakat, hal ini perlu dikaji guna upaya pencegahan dan pengendalian terhadap Penyakit Tidak Menular (PTM) tersebut. Upaya pencegahan dan pengendalian Penyakit Tidak Menular (PTM) dapat dilakukan dengan perilaku hidup sehat. WHO merekomendasikan gaya hidup sehat adalah dengan makan banyak buah-buahan dan sayuran, mengurangi lemak, gula, dan asupan garam serta berolahraga. $^{6}$

Petunjuk Teknis Pos Pembinaan Terpadu (Posbindu) PTM, bahwa saat ini kenaikan kejadian Penyakit Tidak Menular (PTM) telah menjadi ancaman yang serius, khususnya dalam perkembangan kesehatan masyarakat. Salah satu strategi yang dikembangkan pemerintah untuk mengendalikan penyakit tidak menular ini kemudian dikembangkan model Pengendalian Penyakit Tidak Menular (PTM) berbasis masyarakat melalui Pos Pembinaan Terpadu (Posbindu) Penyakit Tidak Menular (PTM).

Posbindu Penyakit Tidak Menular (PTM) merupakan bentuk peran serta masyarakat dalam upaya untuk mengendalikan faktor risiko secara mandiri dan berkesinambungan. Pengembangan Posbindu Penyakit Tidak Menular (PTM) dapat dipadukan dengan upaya 
yang telah terselenggara di masyarakat. Melalui Posbindu Penyakit Tidak Menular (PTM), dapat segera mungkin dilakukan pencegahan faktor risiko Penyakit Tidak Menular (PTM) sehingga kejadian Penyakit Tidak Menular (PTM) di masyarakat Indonesia dapat dikendalikan. ${ }^{7}$

Upaya penanggulangan Penyakit Tidak Menular (PTM) merupakan kombinasi upaya inisiatif pemeliharaan mandiri oleh petugas, masyarakat dan individu yang bersangkutan serta kebijakan promosi kesehatan dan pencegahan penyakit harus ditangkap secara cerdas untuk selanjutnya diimplementasikan kepada masyarakat secara intensif, mengingat banyaknya masyarakat yang belum tahu tentang berbagai faktor resiko yang dapat menyebabkan penyakit, terutama penyakit tidak menular. Pos pembinaan terpadu atau Posbindu merupakan salah satu bentuk dari deteksi dini faktor resiko yang dilakukan secara terus menerus dan berkesinambungan.

Namun berdasarkan kajian literatur, pelaksanaan Posbindu pada hampir seluruh wilayah di Indonesia masih menghadapi berbagai masalah. Masalah-masalah tersebut, diantaranya yaitu: tidak adanya penyuluhan kesehatan, kurangnya pengetahuan dan keterampilan petugas, kurangnya dukungan keluarga masyarakat, dan rendahnya kunjungan.

Berdasarkan data Dinas Kesehatan Kabupaten Nias Selatan tahun 2019, Posbindu Penyakit Tidak Menular (PTM) untuk wilayah Kabupaten Nias Selatan ada sebanyak 63 Posbindu yang tersebar di 35 Kecamatan di Nias Selatan. Salah satu Puskesmas yang memiliki Posbindu terbanyak yaitu Puskesmas Lahusa Kecamatan Lahusa Kabupaten Nias Selatan yaitu sebanyak 12 posbindu, namun jumlah posbindu yang banyak tidak sejalan dengan pemanfaatan Posbindu Penyakit Tidak Menular (PTM) yang masih 3,04\% dari sasaran (Penduduk dengan usia 15 tahun ke atas). Berdasarkan data dari Puskesmas Lahusa Kecamatan Lahusa Kabupaten Nias Selatan, jumlah kunjungan di posbindu Penyakit Tidak Menular (PTM) pada Tahun 2019 sebanyak 1.918 kunjungan. $^{8}$

Berdasarkan hasil survey awal yang dilakukan oleh peneliti dengan melakukan pengamatan dan wawancara dengan 10 orang masyarakat yang pernah berkunjung ke wilayah UPTD Puskesmas Lahusa, diketahui bahwa 9 orang masyarakat kurang berminat melakukan kunjungan di Posbindu Penyakit Tidak Menular (PTM). Dari 9 orang tersebut 5 diantaranya menyatakan bahwa tanpa ke Posbindu mereka akan sembuh sendiri, selain itu mereka juga memiliki persepsi bahwa dengan melakukan kegiatan deteksi dini dan pemantauan faktor risiko Penyakit Tidak Menular (PTM) yang dilaksanakan secara terpadu dan rutin hanya akan menambah stres karena mereka menjadi tahu apa penyakit yang sedang mereka idap sehingga itu hanya akan menambah beban pikiran. Sedangkan 4 orang lainnya menyatakan bahwa percuma berkunjung ke Posbindu karena peran petugas kesehatan masih belum optimal dan cenderung acuh tidak acuh terhadap masyarakat yang datang. Selain itu masyarakat juga menyatakan bahwa peran petugas kesehatan masih belum optimal dalam memberdayakan masyarakat untuk mengikuti kegiatan Posbindu Penyakit Tidak Menular (PTM) sehingga masyarakat memiliki persepsi negatif.

Dinas Kesehatan Kabupaten dan Puskesmas di Kabupaten Nias Selatan telah berupaya untuk menerapkan kebijakan sesuai dengan kebijakan dari pusat yaitu dengan meningkatkan advokasi keijakan yang berpihak terhadap program kesehatan dan sosialisasi P2PTM; melaksanakan upaya promotif, preventif, kuratif, rehabilitatif dan paliatif secara komprehensif; meningkatkan kapasitas sumber daya manusia; mengembangkan dan memperkuat sistem surveilans; penguatan jejaring dan kemitraan melalui pemberdayaan masyarakat.

Berdasarkan paparan di atas, peneliti melihat bahwa perilaku kesehatan masyarakat sangat terkait dengan pemanfaatan layanan kesehatan. Agar seseorang menjadi sehat dan terhindar dari penyakit maka, seseorang harus memiliki perilaku positif. Akan tetapi hasil survey awal yang dilakukan terhadap 10 orang menunjukkan bahwa masih banyak masyarakat Nias Selatan yang memiliki perilaku kesehatan yang buruk, oleh sebab itu penelitian ini bertujuan untuk mengnalisis faktor yang memengaruhi minat berkunjung masyarakat ke pos pembinaan terpadu Penyakit tidak Menular dengan Jumlah Kunjungan di UPTD Puskesmas Lahusa Kecamatan Lahusa Kabupaten Nias Selatan.

\section{BAHAN DAN METODE}

Jenis penelitian yang digunakan dalam penelitian ini adalah survei analitik dengan rancangan cross sectional study. ${ }^{9}$ Penelitian ini dilakukan di UPTD Puskesmas Lahusa Kecamatan Lahusa Kabupaten Nias Selatan. Dilaksanakan Mulai bulan Juli hingga bulan Agustus Tahun 2020. Populasi dalam penelitian ini adalah seluruh masyarakat yang berkunjung ke UPTD Puskesmas Lahusa Kecamatan Lahusa Kabupaten Nias Selatan sebanyak 1.918 orang. Besar sampel 
ditentukan dengan rumus slovin yaitu purposive sampling. ${ }^{10}$ dan sampel dalam penelitian ini yaitu sebanyak 95 orang. Jenis data dalam peneitian ini yaitu data primer melalui kuesioner yang telah disiapkan. Data sekunder merupakan metode pengumpulan data yang diperoleh dari data-data yang telah ada di dokumen-dokumen di UPTD Puskesmas Lahusa Kecamatan Lahusa Kabupaten Nias Selatan dan data tertier adalah data riset yang sudah dipublikasikan secara resmi seperti jurnal dan laporan penelitian (report). ${ }^{11}$ Data dianalisis dengan uji Chi-Square dan uji regresi logistik.

HASIL

Tabel 1. Distribusi Responden di UPTD Puskesmas Lahusa Kecamatan Lahusa Kabupaten Nias Selatan

\begin{tabular}{lrr}
\hline Kelompok Umur & N & \% \\
\hline 26-35 Tahun & 23 & 24,21 \\
36-45 Tahun & 30 & 31,58 \\
46-55 Tahun & 42 & 44,21 \\
\hline JenisKelamin & $\mathbf{N}$ & $\%$ \\
\hline Laki-laki & 37 & 38,95 \\
Perempuan & 58 & 61,05 \\
\hline Jumlah & $\mathbf{9 5}$ & $\mathbf{1 0 0}$ \\
\hline
\end{tabular}

Berdasarkan tabel 1 di atas, diketahui bahwa dari 95 responden, sebagian besar responden berumur 45-55 tahun yaitu sebanyak $42(44,21 \%)$ responden, sedangkan responden lainnya berumur 26-35 tahun

sebanyak $23(24,21 \%)$, sebagian besar responden memiliki berjenis kelamin perempuan yaitu sebanyak $58 \quad(61,05 \%)$ responden.

Tabel 2. Faktor yang berpengaruh terhadap Minat Berkunjung ke Pos Pembinaan Terpadu Penyakit Tidak Menular di UPTD Puskesmas Lahusa Kecamatan Lahusa Kabupaten Nias Selatan

\begin{tabular}{|c|c|c|c|c|c|c|c|}
\hline & \multicolumn{6}{|c|}{ Minat Kunjungan } & \multirow{3}{*}{$\mathrm{p}$ value } \\
\hline & \multicolumn{2}{|c|}{ Tidak } & \multicolumn{2}{|c|}{$\mathrm{Ya}$} & \multicolumn{2}{|c|}{ Total } & \\
\hline & $\mathrm{n}$ & $\%$ & $\mathbf{n}$ & $\%$ & $\mathbf{n}$ & $\%$ & \\
\hline \multicolumn{8}{|l|}{ Pengetahuan } \\
\hline Buruk & 48 & 88,89 & 6 & 11,11 & 54 & 100 & \multirow{2}{*}{0,000} \\
\hline Baik & 10 & 24,39 & 31 & 75,61 & 41 & 100 & \\
\hline \multicolumn{8}{|l|}{ Pendidikan } \\
\hline Rendah & 45 & 80,36 & 11 & 19,64 & 56 & 100 & \multirow[t]{2}{*}{0,000} \\
\hline Tinggi & 13 & 33,33 & 26 & 66,67 & 39 & 100 & \\
\hline \multicolumn{8}{|l|}{ Jarak } \\
\hline Sulit Dijangkau & 45 & 81,82 & 10 & 18,18 & 55 & 100 & \multirow[t]{2}{*}{0,000} \\
\hline Mudah Dijangkau & 13 & 32,50 & 27 & 67,45 & 40 & 100 & \\
\hline \multicolumn{8}{|l|}{ Pekerjaan } \\
\hline Tidak Bekerja & 49 & 89,10 & 6 & 10,90 & 55 & 100 & \multirow[t]{2}{*}{0,000} \\
\hline Bekerja & 9 & 22,50 & 31 & 77,50 & 40 & 100 & \\
\hline \multicolumn{8}{|l|}{ Penghasilan } \\
\hline Pendapatan rendah & 55 & 94,83 & 3 & 5,17 & 58 & 100 & 0,000 \\
\hline Pendapatan Tinggi & 3 & 8,11 & 34 & 81,89 & 37 & 100 & \\
\hline \multicolumn{8}{|l|}{ Dukungan Keluarga } \\
\hline Tidak mendukung & 54 & 93,10 & 4 & 6,89 & 58 & 100 & 0,000 \\
\hline Mendukung & 4 & 10,81 & 33 & 89,19 & 37 & 100 & \\
\hline \multicolumn{8}{|c|}{ Dukungan Petugas Kesehatan } \\
\hline Tidak mendukung & 49 & 98,00 & 1 & 2,00 & 50 & 100 & 0,000 \\
\hline Mendukung & 9 & 20,00 & 36 & 80,00 & 45 & 100 & \\
\hline Total & 58 & 61,05 & 37 & 38,95 & 95 & 100 & \\
\hline
\end{tabular}

Berdasarkan tabel 2 diketahui bahwa ada hubungan pengetahuan terhadap minat berkunjung ke Pos Pembinaan Terpadu Penyakit Tidak Menular di UPTD Puskesmas Lahusa Kecamatan Lahusa Kabupaten Nias
Selatan, ada hubungan pendidikan responden terhadap minat berkunjung ke Pos Pembinaan Terpadu Penyakit Tidak Menular ke UPTD Puskesmas Lahusa Kecamatan Lahusa Kabupaten Nias Selatan, ada hubungan jarak 
terhadap minat berkunjung ke Pos Pembinaan Terpadu Penyakit Tidak Menular ke UPTD Puskesmas Lahusa Kecamatan Lahusa Kabupaten Nias Selatan, ada hubungan pekerjaan terhadap minat berkunjung ke Pos Pembinaan Terpadu Penyakit Tidak Menular ke UPTD Puskesmas Lahusa Kecamatan Lahusa Kabupaten Nias Selatan, ada hubungan penghasilan terhadap minat berkunjung ke Pos Pembinaan Terpadu Penyakit Tidak Menular ke UPTD Puskesmas Tabel 3. Hasil Tahapan Akhir Analisis Regresi Logistik

\begin{tabular}{lcccc}
\hline Variabel & B & P value & Exp(B)OR & 95\%Cl for Exp(B) \\
\hline Pengetahuan & 15,917 & 0,006 & 8,722 & $6,771-11,882$ \\
Jarak & 16,484 & 0.102 & 14,371 & $4,854-1,778$ \\
pekerjaan & 48,616 & 0,111 & 12,000 & $3,738-1,735$ \\
Penghasilan & 64,403 & 0,059 & 10,151 & $4,859-7,524$ \\
Dukungan keluarga & 68,330 & 0,003 & 14,733 & $8,338-12,325$ \\
\hline
\end{tabular}

Berdasarkan tabel 3 di atas dapat dilihat bahwa pada tahap akhir analisis regresi logistik menghasilkan 1 (satu) variabel yang paling dominan berpengaruh terhadap minat berkunjung di Pos Pembinaan Terpadu (Posbindu) Penyakit Tidak Menular (PTM) di UPTD Puskesmas Lahusa Kecamatan Lahusa Kabupaten Nias Selatan Tahun 2020 dengan $p$ value < 0,05, yaitu variabel dukungan keluarga dengan signifikan 0,003 ( $p$ value < $0,05), \mathrm{OR}=10,151(95 \% \mathrm{Cl}=4,859-7,524)$ artinya responden yang tidak mendapatkan dukungan keluarga mempunyai peluang 10,151 kali tidak berminat melakukan kunjungan dengan nilai koefisien $B$ yaitu 64,403 bernilai positif, semakin banyak responden yang tidak mendapatkan dukungan keluarga maka semakin banyak pula responden yang tidak berminat melakukan kunjungan ke Pos Pembinaan Terpadu Penyakit Tidak Menular di UPTD Puskesmas Lahusa Kecamatan Lahusa Kabupaten Nias Selatan.

Berdasarkan nilai Negelkerke $\mathrm{R}$ Square menunjukan nilai koefisien determinasi di dapat nilainya 0,859 yang artinya $8,59 \%$ variabel persepsi masyarakat berkontribusi terhadap kunjungan ke Pos Pembinaan Terpadu Penyakit Tidak Menular di UPTD Puskesmas Lahusa Kecamatan Lahusa Kabupaten Nias Selatan, sedangkan 1,41\% dipengaruhi oleh variabel lain yang tidak diteliti dalam penelitian ini.

\section{PEMBAHASAN}

Pengetahuan atau kognitif merupakan domain yang sangat penting untuk terbentuknya tindakan masyrakat di UPTD Puskesmas Lahusa Kecamatan Lahusa Kabupaten Nias Selatan. Pengetahuan tentang posbindu akan mempengaruhi
Lahusa Kecamatan Lahusa Kabupaten Nias Selatan, ada hubungan dukungan keluarga terhadap minat berkunjung ke Pos Pembinaan Terpadu Penyakit Tidak Menular ke UPTD Puskesmas Lahusa Kecamatan Lahusa Kabupaten Nias Selatan, ada hubunagn dukungan petugas kesehatan terhadap minat berkunjung ke Pos Pembinaan Terpadu Penyakit Tidak Menular ke UPTD Puskesmas Lahusa Kecamatan Lahusa Kabupaten Nias Selatan. perilaku masyarakat dalam pemanfaatan pelayanan puskesmas. Pengetahuan sangat penting peranannya karena dengan adanya pengetahuan yang dimiliki masyarakat, maka akan terbentuk sikap yang akan diikuti dengan tindakan memilih pelayanan kesehatan yang baik.

Prasangka dan stigma buruk yang menyertai masyarakat menyebabkan kesulitan yang dihadapi masyarakat bertambah adalah akibat dari buruknya pengetahuan yang dimiliki oleh masyarakat, begitupun sebaliknya stigma baik dan penerimaan serta perlakuan yang baik dari masyarakat membantu seseorang beserta keluarganya dalam menghadapi masalah yang muncul dan mengurangi beban secara subyektif maupun beban obyektif, serta memotivasi dalam proses kesembuhan. Adanya pengetahuan masyarakat yang baik membuat individu akan merasa tetap percaya diri, tidak mudah putus asa, tidak minder, merasa dirinya bersemangat, merasa ikhlas dengan kondisi, sehingga merasa lebih tenang dalam mengadapi suatu masalah.

Pengetahuan masyarakat yang kurang di UPTD Puskesmas Lahusa Kecamatan Lahusa Kabupaten Nias Selatan menjadikan masyarakat memiliki prasangka dan stigma buruk tentang pelayanan yang Posbindu, sehingga hal tersebut menyebabkan kesulitan yang dihadapi masyarakat bertambah adalah akibat dari buruknya pengetahuan yang dimiliki oleh masyarakat maka tidak banyak masyrakat yang berminat melakukan kunjungan ke UPTD Puskesmas Lahusa Kecamatan Lahusa Kabupaten Nias Selatan. Stigma buruk tersebut menyebabkan masyrakat menjadi kurang menyukai memanfaatkan posbindu Begitupun sebaliknya stigma baik dan penerimaan serta 
perlakuan yang baik dari masyarakat membantu seseorang beserta keluarganya dalam menghadapi masalah yang muncul dan mengurangi beban secara subyektif maupun beban obyektif, serta memotivasi dalam proses kesembuhan.

Kurangnya pengetahuan masyarakat di UPTD Puskesmas Lahusa Kecamatan Lahusa Kabupaten Nias Selatan mengenai pelayanan kesehatan akan mempengaruhi pemanfaatan fasilitas pelayanan yang ada sehingga berpengaruh pada kondisi kesehatan mereka. Peningkatan akan pelayanan kesehatan tergantung dari pengetahuan mengenai apa yang ditawarkan dalam pelayanan tersebut, bagaimana serta kapan dan oleh siapa serta dengan biaya berapa. Banyak masyrakat yang menyatakan responden tidak mengetahui tentang adanya Posbindu PTM disekitar tempat tinggalnya, ini menunjukkan bahwa informasi yang didapatkan masyarakat masih sangat kurang, bahkan beberapa responden menyatakan hanya mengetahui tentang adanya pemeriksaan kesehatan gratis. Padahal yang dimaksud dalam hal itu adalah Posbindu PTM. Keterjangkauan informasi mengenai Posbindu PTM ini hanya pada masyarakat sekitar tempat pelaksanaan Posbindu. Beberapa responden mengaku mengetahui adanya Posbindu tapi tidak tertarik untuk berkunjung. Kurangnya sosialisasi ataupun informasi mengenai manfaat Posbindu PTM tentu mempengaruhi motivasi masyarakat untuk memanfaatkan.

Prasangka dan stigma buruk yang menyertai masyarakat menyebabkan kesulitan yang dihadapi masyarakat bertambah adalah akibat dari buruknya pengetahuan yang dimiliki oleh masyarakat. begitupun sebaliknya stigma baik dan penerimaan serta perlakuan yang baik dari masyarakat membantu seseorang beserta keluarganya dalam mengahdapi masalah yang muncul dan mengurangi beban secara subyektif maupun beban obyektif, serta memotivasi dalam proses kesembuhan. Adanya dukungan dari masyarakat membuat individu akan merasa diperdulikan, diperhatikan, merasa tetap percaya diri, tidak mudah putus asa, tidak minder, merasa dirinya bersemangat, merasa ikhlas dengan kondisi, sehingga merasa lebih tenang dalam mengadapi suatu masalah. Pengetahuan tentang posbindu akan mempengaruhi perilaku masyarakat dalam pemanfaatan pelayanan puskesmas.

Pengetahuan sangat penting peranannya karena dengan adanya pengetahuan yang dimiliki masyarakat maka akan terbentuk sikap yang akan diikuti dengan tindakan memilih pelayanan kesehatan yang baik. Pada penelitian ini, peneliti akan menganalisis bagaimana pengetahuan masyarakat tentang pemanfaatan Posbindu, apa yang melatarbelakangi masyarakat datang atau tidak berkunjung ke Posbindu.

Menurut peneliti, masyarakat yang memiliki pengetahuan kurang tentang Posbindu PTM dikarenakan informasi yang didapatkan masyarakat tentang Posbindu PTM kurang seperti kurangnya pengetahuan masyarakat mengetahui manfaat dari Posbindu PTM dan kurangnya penyuluhan-penyuluhan yang diberikan oleh petugas kesehatan. Posbindu PTM banyak memberikan manfaat bagi masyarakat yang mengikutinya, salah satunya adalah merasakan perubahan dalam kesehatan setelah mengikuti Posbindu PTM.

Masyarakat yang mengetahui manfaat dari posbindu PTM sering melakukan pemeriksaan ke Posbindu PTM sehingga masyarakat tersebut mengetahui kondisi kesehatan setiap bulannya. Berdasarkan hal tersebut perlunya masyarakat untuk mengetahui manfaat dari Posbindu PTM yang didapatkan melalui penyuluhan-penyuluhan dari petugas kesehatan sehingga diharapkan nantinya masyarakat mengalami perubahan yang semakin membaik pada kesehatannya seperti pada masyarakat sehat agar kondisinya tetap normal dan pada masyarakat penyandang PTM agar mencegah timbulnya komplikasi.

Informasi dari tenaga kesehatan seperti penyuluhan kepada masyarakat sangat penting dilakukan untuk meningkatkan pengetahuan masyarakat tentang Posbindu PTM. Paparan informasi seperti penyuluhan yang terus-menerus dilakukan akan menyebabkan semakin meningkatnya tingkat pengetahuan yang baik khususnya bagi masyarakat usia produktif di Banjar Busung Yeh Kauh Kelurahan Pemecutan.

Menurut peneliti kurangnya minat masyarakat tentang pemanfaatan Posbindu PTM disebabkan karena beberapa faktor seperti kurangnya perilaku masyarakat yang berusaha untuk menghadiri kegiatan Posbindu agar bisa berkumpul dengan teman-teman yang sebaya. Kurangnya pengetahuan yang dimiliki oleh masyarakat juga dapat mempengaruhi kepatuhan pemanfaatan Posbindu PTM, dimana masyarakat hanya datang ke Posbindu PTM jika ada petugas kesehatan seperti dokter dan perawat, masyarakat juga hadir jika ada pemeriksaan khusus seperti pemeriksaan gula darah, kolesterol dan lain-lain. Ketidakminatan masyarakat untuk hadir di Posbindu PTM juga disebabkan juga karena kurangnya informasi dan dukungan yang diberikan oleh keluarga tentang pelaksanaan Posbindu dan juga 
kurangnya informasi yang diberikan oleh Petugas Posbindu PTM. Sebagian besar masyarakat terutama yang mendapat penyakit dan tidak merasakan sakit tentu tidak akan bertindak apa-apa terhadap penyakitnya tersebut, dengan alasan bahwa kondisinya tidak akan menganggu kegiatan mereka sehari-hari dan mereka beranggapan bahwa tanpa bertindak apapun penyakitnya akan hilang dengan sendirinya. Hal ini membuktikan bahwa perilaku masyarakat tentang kesehatan dan pemanfaatan pelayanan kesehatan masih kurang dalam mengikuti pos pembinaan terpadu penyakit tidak menular seperti deteksi dini dan pemantauan faktor risiko penyakit tidak menular. Oleh karena itu, masih perlu upaya yang dilakukan dalam meningkatkan pemanfaatan pelayanan kesehatan Berdasarkan hal tersebut sangat diperlukan kepatuhan masyarakat dalam mengikuti posbindu penyakit tidak menular. Pos pembinaan terpadu penyakit tidak menular pada masyarakat tidak dipungkiri lagi bahwa faktor yang mempengaruhi kepatuhan pemanfaatan pos pembinaan terpadu penyakit tidak menular antara lain seperti umur, jenis kelamin, pendidikan, pekerjaan, perilaku, petugas kesehatan, petugas , jarak rumah, dukungan keluarga, teman sebaya, pengetahuan.

Tingkat pendidikan masyarakat di wilayah kerja UPTD Puskesmas Lahusa Kecamatan Lahusa Kabupaten Nias Selatan merupakan salah satu faktor predisposisi yang mempengaruhi pemanfaatan Posbindu PTM oleh masyarakat. Status pendidikan berpengaruh terhadap pemanfaatan pelayanan kesehatan karena status pendidikan akan mempengaruhi kesadaran dan pengetahuan tentang kesehatan. Sehingga promosi tentang diadakannya posbindu PTM perlu digalakkan oleh petugas kesehatan dengan harapan masyarakat termotivasi dalam pemanfaatan Posbindu PTM.

Tingkat pendidikan masyarakat di UPTD Puskesmas Lahusa Kecamatan Lahusa Kabupaten Nias Selatan sangat berpengaruh terhadap berminat atau tidaknya masyrakat tersebut berkunjung untuk memanfaatkan posbindu PTM ini. Orang yang berpendidikan tinggi akan memberikan respon yang rasional terhadap informasi yang datang, akan berfikir sejauh mana keuntungan yang mungkin akan mereka peroleh dari hal tersebut. Tingkat pendidikan yang rendah akan mempersempit wawasan seseorang sehingga makin sulit untuk menerima informasi yang bermanfaat bagi dirinya.
Jarak tempat tinggal masyrakat di wilayah kerja UPTD Puskesmas Lahusa Kecamatan Lahusa Kabupaten Nias Selatan dapat menjadi faktor pendorong seseorang untuk melakukan kunjungan ulang, karena keterjangkauan jarak dapat mempengaruhi seseorang dalam melakukan kunjungan berobat ke fasilitas kesehatan. Semakin tidak terjangkau tempat yang ditempuh seseorang dari tempat tinggal ke pelayanan kesehatan maka semakin tidak berminat orang melakukan kunjungan. Semakin tidak terjangkau jarak tempat tinggal dengan pelayanan kesehatan akan semakin menurunnya motivasi seseorang untuk berkunjung ke pelayanan kesehatan.

Berdasarkan hasil penelitian dengan responden menggunakan kuesioner. Beberapa responden memiliki jarak rumah yang jauh dan tidak dapat dijangkau oleh masyarakat. Jarak rumah yang jauh mengakibatkan responden memilih cek kesehatan di fasilitas kesehatan terdekat, seperti Bidan Desa dan Pustu. Beberapa responden yang memiliki jarak rumah dekat dan terjangkay dan tidak aktif mengikuti Posbindu PTM hal ini dikarenakan mereka memiliki pekerjaan yang sulit untuk ditinggalkan, jadi mereka memilih bekerja karena mereka menganggap untuk cek tensi, cek gula darah, cek kolesterol dan cek asam urat bisa dilakukan di bidan desa yang bisa dikunjungi kapan saja. Sedangkan beberapa responden yang memiliki jarak rumah jauh dan aktif mengikuti Posbindu PTM hal ini dikarenakan mereka mengetahui manfaat dari Posbindu PTM dan bisa mengendarai sepeda motor sendiri, sehingga mereka rela meninggalkan pekerjaannya demi kesehatannya.

Menurut asumsi peneliti, pada umumya seseorang akan mencari tempat pelayanan ke fasilitas kesehatan yang berlokasi dekat dengan tempat tinggal mereka. Selain itu, jarak posyandu yang dekat dengan tempat tinggal tentunya akan memudahkan seseorang dalam menjangkaunya tanpa harus mengalami kelelahan fisik. Kemudian dalam menjangkau posyandu juga membuat seseorang merasa lebih aman dan nyaman sehingga mendorong minat untuk memanfaatkannya.

Pekerjaan adalah profesi yang sedang seseorang geluti sesuai dengan bidangnya dengan tujuan untuk memperoleh penghargaan atau jerih payah dari semua yang dia lakukan dalam bidang tersebut. Seorang dikatakan memiliki pekerjaan ketika seseorang tersebut menggeluti sebuah aktivitas atau kegiatan yang akan menghasilkan produk. 
Status bekerja maupun tidak bekerja tidak mempengaruhi masyarakat dalam hal memanfaatkan Posbindu PTM. Masyarakat dengan status tidak bekerja tentu memiliki peluang ataupun kesempatan yang lebih besar untuk memanfaatkan pelayanan yang ada karena sebagian besar waktu mereka habiskan dirumah dibandingkan mereka yang bekerja. Tetapi pada penelitian ini, responden dengan status tidak bekerja lebih banyak tidak memanfaatkan posbindu. Hal ini dikarenakan mayarakat tidak didukung oleh kesadaran dan pengetahuan tentang manfaat posbindu. Sebagian besar responden tidak mengetahui, sehingga mempengaruhi pemanfaatannya. Sebagian besar memilih untuk memeriksakan kesehatannya di puskesmas ketika sakit.

Menurut peneliti adanya kecenderungan seseorang yang bekerja lebih aktif mencari pelayanan kesehatan dibandingkan dengan yang tidak bekerja, disebabkan karena disamping pengetahuannya lebih tinggi, juga karena mereka lebih mandiri secara ekonomi. Selain itu, faktor aksesibilitas juga mempengaruhi jumlah kunjungan posbindu. Masyarakat dengan jarak rumah yang jauh dari lokasi pelaksanaan posbindu memungkinkan mereka untuk tidak memanfaatkan. Dari hasil pengamatan peneliti, masyarakat yang memanfaatkan adalah mereka yang bertempat tinggal dekat dengan tempat pelaksanaan posbindu sehingga kurang menjangkau masyarakat yang bertempat tinggal jauh.

Menurut peneliti, penghasilan atau Ekonomi, penghasilan menentukan tingkat hidup seseorang terutama dalam kesehatan. Apabila penghasilan yang didapat berlebih, maka seseorang lebih cenderung untuk menggunakan fasilitas kesehatan yang lebih baik, contohnya seperti rumah sakit dengan fasilitas yang ada di lingkungan tempat tinggalnya. Peningkatan akan pelayanan kesehatan tergantung dari pengetahuan mengenai apa yang ditawarkan dalam pelayanan tersebut, bagaimana serta kapan dan oleh siapa serta dengan biaya berapa. Penelitian Nasruddin (2017), menyatakan adanya hubungan antara pengetahuan dengan pemanfaatan Posbindu PTM. ${ }^{12}$ Sebagian besar responden tidak mengetahui tentang adanya Posbindu PTM disekitar tempat tinggalnya, ini menunjukkan bahwa informasi yang didapatkan masyarakat masih sangat kurang, bahkan beberapa responden menyatakan hanya mengetahui tentang adanya pemeriksaan kesehatan gratis. Padahal yang dimaksud dalam hal itu adalah Posbindu PTM. Keterjangkauan informasi mengenai Posbindu PTM ini hanya pada masyarakat sekitar tempat pelaksanaan Posbindu. Beberapa responden mengaku mengetahui adanya Posbindu tapi tidak tertarik untuk berkunjung. Kurangnya sosialisasi ataupun informasi mengenai manfaat Posbindu PTM tentu mempengaruhi motivasi masyarakat untuk memanfaatkan.

Dukungan sosial adalah suatu keadaan yang bermanfaat bagi individu yang diperoleh dari orang lainyang dapat dipercaya, sehingga seseorang akan tahu bahwa ada orang lain yang memperhatikan, menghargai, dan mencintainya. Dukungan keluarga adalah sikap, tindakan, dan penerimaan keluarga dengan penderita yang sakit. Semua tahapan dukungan sosial keluarga menjadikan keluarga mampu berfungsi dengan berbagai kepandaian dan akal, sehingga akan meninggalkan kesehatan dan adaptasi mereka dalam kehidupan. Studi tentang dukungan keluarga telah mengkonseptualisasi dukungan sosial sebagai koping keluarga, baik dukungan yang bersifat eksternal maupun internal terbukti sangat bermanfaat. Dukungan sosial keluarga eksternal antara lain sahabat, pekerjaan, tetangga, sekolah, keluarga besar, kelompok sosial, kelompok rekreasi, dan praktisi kesehatan.

Individu sangat membutuhkan dukungan sosial yang salah satunya berasal dari dukungan keluarga. Dukungan keluarga yang rendah tersebut disebabkan karena anggota keluarga yang bekerja, sehingga kurang memperhatikan pentingnya pemeriksaan kesehatan dalam upaya pencegahan penyakit. Dukungan keluarga sangat berperan dalam mendorong minat atau kesediaan seseorang untuk mengikuti kegiatan Posbindu. Kehadiran penduduk dalam Posbindu yang rendah dapat dipengaruhi oleh kurangnya dukungan keluarga. $^{13}$

Dukungan keluarga yang kurang dapat menurunkan keaktifan seseorang untuk mengikuti Posbindu PTM, dan sebaliknya dukungan keluarga yang tinggi akan meningkatkan keaktifan seseorang dalam mengikuti Posbindu PTM. Dukungan keluarga untuk mendorong seseorang mengikuti Posbindu PTM adalah dengan mendampingi, mengantar, atau mengingatkan jadwal kegiatan Posbindu PTM. Apabila ada dukungan dari keluarga, rasa percaya diri akan bertambah dan memotivasi untuk mengikuti Posbindu. Dukungan keluarga yang kurang banyak disebabkan karenakurangnya pengetahuan dari anggota keluarga terhadap kegiatan Posbindu.

Dukungan keluarga yang kurang dapat menurunkan keaktifan seseorang untuk mengikuti Posbindu PTM, dan sebaliknya 
dukungan keluarga yang tinggi akan meningkatkan keaktifan seseorang dalam mengikuti Posbindu PTM. Dukungan keluarga untuk mendorong seseorang mengikuti Posbindu PTM adalah dengan mendampingi, mengantar, atau mengingatkan jadwal kegiatan Posbindu PTM. Apabila ada dukungan dari keluarga, rasa percaya diri akan bertambah dan memotivasi untuk mengikuti Posbindu.

Dukungan ini terjadi lewat ungkapan hormat positif untuk anggota keluarga, dorongan untuk maju atau persetujuan dengan gagasan atau perasaan individu dan perbandingan positif orang tersebut dengan orang lain. Pemberian dukungan ini membantu anggota keluarga untuk melihat segi-segi positif yang ada dalam dirinya dibandingkan dengan keadaan orang lain yang berfungsi untuk menambah penghargaan diri, membentuk kepercayaan diri dan kemampuan serta merasa dihargai dan berguna saat individu mengalami tekanan.

Penelitian ini sejalan dengan penelitian yang dilakukan oleh Dwi Wigati Ratna Sari dan Mieke Safitri (2018) yang meneliti tentang faktor-faktor yang berhubungan dengan pemanfaatan Posbindu PTM di Wilayah Kerja Puskesmas Kecamatan Setiabudi Kota Jakarta Selatan yang salah satu dari variabel bebasnya adalah dukungan keluarga terhadap pemanfaatan Posbindu PTM. Penelitian tersebut menyatakan bahwa $\mathrm{p}$-valuesebesar 0,037 yang berarti ada hubungan antara dukungan keluarga dengan pemanfaatan Posbindu PTM, sedangkan nilai ORsebesar 2,153 artinya responden yang mendapat dukungan keluarga lebih besar 2,153 akan lebih besar untuk aktif memanfaatkan Posbindu PTM. ${ }^{14}$

Menurut peneliti, peluarga sebagai motivator kuat bagi penduduk untuk mengikuti kegiatan posbindu PTM apabila selalu menyediakan diri untuk mendampingi, mengantar atau mengingatkan jadwal posbindu PTM. Keberadaan anggota keluarga memainkan peranan penting dalam mencegah atau paling tidak menunda orang menderita sakit kronis ke lembaga pelayanan kesehatan. Besarnya keterlibatan dan sifat pelayanan yang diberikan keluarga tergantung pada sumber-sumber ekonomi, struktur keluarga, kualitas hubungan, kebutuhan lainnya dan tenaga yang tersedia.

Dukungan petugas kesehatan yang bekerja di lapangan sangatlah penting dalam keberhasilan program untuk mencapai target pelaksanaan posbindu pada masyarakat khususnya peran sebagai edukasi dan pelaksana. Kualitas pelayanan dan sikap petugas merupakan cerminan keberhasilan dalam strategi pelaksanaan. Diharapkan tenaga kesehatan lebih proaktif dalam melaksanakan perannya untuk mendukung program pencapaian target status pelaksanaan posbindu khususnya peran sebagai edukasi dengan melakukan penyuluhan atau konseling dengan bantuan media atau alat bantu seperti poster, leaflet, dan lain-lain. Peran sebagai pelaksana/pelayanan yang dilakukan tidak hanya di Puskesmas saja tetapi juga dengan kunjungan rumah serta lebih pro aktif menganjurkan masyarakat untuk melakukan kunjungan dan memeriksakan kesehatannya ke posbindu dan mengingatkan jadwal kontrol serta melakukan pendokumentasian dengan lengkap

Dari hasil penelitian didapatkan beberapa alasan ketidakhadiran responden dalam kegiatan Posbindu PTM yaitu, responden tidak mengetahui jadwal kegiatan Posbindu PTM dan jadwal kegiatan Posbindu PTM yang diinformasikan secara mendadak. Dimana hal tersebut merupakan salah satu tugas dari petugas Posbindu PTM yaitu menginformasikan waktu pelaksanaan kegiatan beberapa hari sebelum kegiatan berlangsung. Beberapa responden menyatakan tidak diberitahukan perihal manfaat dari Posbindu PTM. Selain itu antrian yang ramai pada saat pemeriksaan dalam kegiatan Posbindu PTM menjadi keluhan beberapa responden. Upaya peningkatan kualitas petugas sangat perlu dilakukan dalam untuk memberikan motivasi dan informasiinformasi terkait kesehatan juga memfasilitasi kegiatan promosi kesehatan.

Bila petugas tidak memberikan informasi kepada masyarakat maka mereka tidak akan memanfaatkan pelayanan posbindu. Petugas selain mempunyai tugas dan fungsi juga harus mampu berkomunikasi dengan baik dan mampu mengajak dan memotivasi kelompok maupun masyarakat. Petugas harus juga dapat membina semua yang terkait dengan pelaksanaan posbindu, tetapi memantau perkembangan penyakitnya.

Menurut peneliti, kurangnya inisiatif petugas dalam mengajak masyarakat untuk memeriksakan kesehatannya di posbindu menyebabkan kurangnya pula motivasi masyarakat untuk berkunjung. $\mathrm{Hal}$ ini menyebabkan perlunya monitoring dan evaluasi terhadap pelaksanaan posbindu sehinggakualitas pelayanannya menjadi lebih baik. Untuk meningkatkan citra diri petugas maka harus diperhatikan dan meningkatkan kualitas diri sebagai petugas ebagian besar responden menyatakan tidak pernah 
mendapatkan sosialisasi maupun informasi mengenai Posbindu PTM dari tenaga kesehatan maupun petugas .Belum terbentuknya perilaku responden yang baik dalam memanfaatkan pelayanan kesehatan sangat dipengaruhi adanya peran petugas kesehatan secara terus menerus dan berkesinambungan dalam melakukan pendekatan dan memberikan informasi kesehatan kepada masyarakat

\section{DAFTAR PUSTAKA}

1. WHO. A Global Brief On Hypertension: Silent Killer, Global Public Health Crisis. Http://Apps.Who.Int//ris/Bitstream

2. Amiruddin, R. Mengembangkan Evidence Based Public Health (Ebph) Hiv Dan Aids Berbasis Surveilans. Jurnal Adminsitrasi \& Kebijakan Kesehatan Indonesia; 2017.

3. Kementrian Kesehatan RI. Profil Kesehatan Indonesia 2017. Jakarta: Kemenkes RI. Diakses Pada Tanggal Diakses Januari 2020 Dari Http://Www.Depkes.Go.Id/Resources/ Download/Pusdatin/Profil-KesehatanIndonesia/Profil-Kesehatan-IndonesiaTahun-2017.Pdf; 2018

4. Balitbang Kemenkes RI. Riset Kesehatan Dasar; RISKESDAS.Jakarta: Balitbang Kemenkes RI; 2018

5. Dinas Kesesehatan Provinsi Sumatera Utara. Profil Kesehatan Provinsi Sumatera Utara; 2018

6. WHO. A Global Brief On Hypertension: Silent Killer, Global Public Health Crisis. Http://Apps.Who.Int//ris/Bitstream
7. Keputusan Menteri Kesehatan Republik Indonesia Nomor 1116/MENKES/SK/VIII/2003 Tentang Pedoman Penyelenggaran Sistem Surveilans Epidemiologi Kesehatan.

8. Profil Dinas Kesehatan Kabupaten Nias Selatan Tahun 2019

9. Notoatmodjo,S. Metodologi Penelitian Kesehatan. Jakarta. Rineka Cipta.; 2013.

10. Amirin, T. Populasi Dan Sampel Penelitian 4: Ukuran Sampel Rumus Slovin, Erlangga, Jakarta; 2011

11. Bajari, Atwar. Metode Penelitian Komunikasi: Prosedur, Tren Dan Etika. Bandung: PT. Remaja Rosdakarya; 2015.

12. Nasruddin, Nurizka Rayhana. Faktor-

Faktor Yang Mempengaruhi Pemanfaatan Pos Pembinaan Terpadu Penyakit Tidak Menular (POSBINDU PTM) Di Wilayah Kerja Puskesmas Ballaparang Kota Makassar Tahun 2017 Phd Thesis. Universitas Islam Negeri Alauddin Makassar; 2017

13. NOTOADMODJO, S. Pemberdayaan Masyarakat. Jakarta: Rineka Cipta Jakarta: Rajawali Pers, 2010.

14. SARI, Dwi Wigati Ratna; SAVITRI, Mieke. Faktor-Faktor Yang Berhubungan Dengan Pemanfaatan POSBINDU Penyakit Tidak Menular (PTM) Di Wilayah Kerja PUSKESMAS Kecamatan Setia Budi Kota Jakarta Selatan Tahun 2018. Jurnal Kebijakan Kesehatan Indonesia: JKKI, 2018, 7.2: 49-56. 